Trinity University

Digital Commons @ Trinity

Library Faculty Research

Coates Library

$11-2015$

\title{
The Joy of Combining Librarianship and Motherhood
}

Alexandra Gallin-Parisi

Trinity University, agallin@trinity.edu

Follow this and additional works at: https://digitalcommons.trinity.edu/lib_faculty

Part of the Library and Information Science Commons

\section{Repository Citation}

Gallin-Parisi, A. (2015). The joy of combining librarianship and motherhood. The Journal of Academic Librarianship, 41(6), 839-846. doi: 10.1016/j.acalib.2015.09.002

This Post-Print is brought to you for free and open access by the Coates Library at Digital Commons @ Trinity. It has been accepted for inclusion in Library Faculty Research by an authorized administrator of Digital Commons @ Trinity. For more information, please contact jcostanz@trinity.edu. 
The Joy of Combining Librarianship and Motherhood

\author{
Alexandra Gallin-Parisi \\ Instruction Librarian and Assistant Professor
}

Trinity University

Elizabeth Huth Coates Library

1 Trinity Place

San Antonio, TX 78212

agallin@ trinity.edu 
The Joy of Combining Librarianship and Motherhood 2

\section{ABSTRACT}

While there is a rich literature about how academic faculty manage to balance work and family life, there is a surprising paucity of research centered on academic librarianship and motherhood. In this phenomenological study based on interviews, the lived experiences of 21 librarians who are also mothers of young children are explored. Six themes focused on the benefits and rewards of combining librarianship and motherhood emerge.

\section{KEYWORDS}

academic librarians, motherhood, qualitative methods, interviews, work-family enrichment

\section{INTRODUCTION}

"Being a librarian has made me a better mother, and being a mom has actually made me a better librarian." -Nicole, a research and instruction librarian and mother of one-year-old twins

In this era of mommy-blogs, mommy-wars, perfect madness, Mama, PhD, Professor Mommy, and "do babies matter?," the question really is, What more can possibly be said about the experiences of women combining work and family? Surprisingly, librarians have remained relatively silent in this conversation, even in academic circles, and so little is known about what librarians' experiences look like. While many academic librarians hold faculty positions and may even be on the tenure-track, librarians' daily responsibilities, schedules, and employment contracts often mean that a librarian has much less flexibility, autonomy, and off-campus time than her teaching faculty colleagues. Many librarians, both those with faculty status and those who are considered administrative staff, find that they are in a unique position in higher

\footnotetext{
${ }^{1}$ This list comprises a mere sliver of the cultural references, popular book titles, and latest salvoes in the discussion of motherhood in the United States over the last decade.
} 
The Joy of Combining Librarianship and Motherhood 3

education, and so the plethora of studies about how faculty manage their dual roles as

professionals and parents does not always resonate. The present study seeks to illuminate the experiences of librarians and to thereby push the investigation of the work-family interface into this less-explored arena.

The research reported in this article represents the first part of a larger study of the experiences of academic librarians who are also mothers of young children. The purpose here is to answer the following question: What are the benefits women experience in combining the roles of librarian and mother? The above quotation from one of the study participants acts as a springboard into this exploration of role symbiosis. This noticeably positive perspective is a much-needed one, as the popular and scholarly literature is littered with the language of conflict and struggle. This is not to ignore the tension and challenges that all women combining the two roles face; this positive perspective is only one part of the bigger story, yet a frequently ignored one. It is important to note that not all the women interviewed experienced all of the joys described in the following study, and a few women had more negative than positive experiences with combining librarianship and motherhood. All of the women did cite at least one joy derived from managing both roles. Through this article, the intention of the author is not only to share research findings with colleagues, administrators, and graduates considering entering the field of librarianship, but also to inspire an honest conversation about this topic within the profession.

\section{LITERATURE REVIEW}

\section{Academia and Motherhood.}

Research narratives and academic lore reinforce the incompatibility of developing a successful academic career while investing time, love, and energy into motherhood. By repeating 
a "narrative of constraint" (O’Meara et al., 2008), the literature suggests that women who want both - a productive career in academia and children — must either concede and choose one to the detriment of the other or must acquire superhuman powers to overcome the endless threats to their success. It is easy to find substantial studies warning early-career faculty about the dangers of mixing the two roles (e.g., Munn-Giddings, 1998; Armenti, 2004), detailing the perceived barriers (e.g., Van Anders, 2004), or highlighting the stresses and lack of support experienced by academic mothers (e.g., O’Laughlin \& Bischoff, 2005). In their telling 2004 joint report, "Sleepless in Academia," Acker and Armenti combined their two qualitative studies of female Canadian faculty with children to highlight the challenges, discontents, and daily dilemmas faced by faculty-mothers. The aforementioned studies are invaluable contributions to the understanding of women's role in the workplace, and more specifically, female faculty's relationship with parenthood, but in many ways, they continue the conflict perspective.

Alternatively, there is a current body of research investigating the higher-education policies that affect female faculty, especially regarding work/family issues (e.g., Hollenshead, 2005; Ward \& Wolf-Wendel, 2005; Bird, 2011). Although the participants in the present study were asked about the institutional support they received as mothers from their employers' policies (i.e., parental leave, flexible scheduling, access to breastfeeding/pumping rooms), policy and institutional transformation are not the focus of this study.

The present study more-closely follows in the steps of the work done by Raddon in the United Kingdom and Ward and Wolf-Wendel in the United States. Raddon (2005) explores the "lived reality" of women academics positioned in-between the often-contradictory discourses of the "successful academic" and the "good mother." She asserts that despite the tension between a woman's dual roles, there is still potential for empowerment and even fulfillment. The present 
study builds on this concept of empowerment and agency by highlighting the benefits, joy, and satisfaction experienced by librarians who are mothers of young children.

Additionally, Ward and Wendel's 2004 article and subsequent book, Academic

Motherhood: How Faculty Manage Work and Family (2012) were the inspiration for the present study, because in these works, the authors make an effort to combat the "narrative of constraint" and thereby leave room for what they label the "silver linings" of combining academia with being a mother. The rare glimmer of hope and happiness was a welcome respite from the doom and gloom of much of the scholarly and popular literature on motherhood. It serves as a springboard for the examination of the rewards of dual roles. The present study's positive perspective on combining work and family is intended as a complement to, not a denigration of, the often-challenging and problematic reality of motherhood in the United States. Prior studies exploring the very real hardships faced by full-time-employed mothers of young children play a valuable role in changing our current socio-political system in the U.S., which is characterized by an egregious lack of support for families. This study adds a worthwhile expansion of the discussion about motherhood by focusing on the sometimes-overlooked rewards. The title of the present study, "The Joy of Combining Librarianship and Motherhood," is inspired by a chapter subheading in Ward and Wolf-Wendel (2004; 2012): “The Joy of Professional and Personal Roles."

\section{Work-Family Enrichment.}

It is worth noting that there is a growing interest at the crossroads between the fields of management and industrial-organizational psychology in the positive effects of combining the dual roles of work life and family life. Research studies in these fields have investigated the concept using terms such as "interrole facilitation," "positive spillover," "enrichment," and 
The Joy of Combining Librarianship and Motherhood 6

"enhancement" and have begun to formulate theoretical frameworks for exploring these positive effects (see Greenhaus \& Powell, 2006 for a review). Work-family enrichment is defined as "the extent to which experiences in one role improve the quality of life in the other role" (Greenhaus \& Powell, 2006, p. 73). This bi-directionality between work and family life is important, and for the purposes of the present study, the author will use the term "work-family enrichment." Several of the "silver linings" referred to by Ward and Wolf-Wendel fit nicely into this concept.

\section{Librarianship and Motherhood.}

Despite the perennial conversation surrounding faculty and motherhood, academic librarians' voices are noticeably absent. Librarianship is not only a culturally feminized profession, but a female-dominated one: according to the National Center of Education Statistics, women comprise $81 \%$ of library school enrollment, and according to the ARL Annual Salary Survey, over $62 \%$ of their library professionals are women and women make up the majority of research library directors (58\%). Graves, Xiong, and Park (2008) posit that librarians' relative silence on this important topic may stem from the controversial nature of tenure within librarianship; perhaps the sometimes-ambiguous status of librarians is to blame for the professional reticence to tackle these issues. Essays and autobiographical sketches pop up now and then in journals and on professional blogs, often offering a first-person perspective and maybe a call for changes in policy or attitude. Recently, personal anecdotes, useful strategies, and policy recommendations were combined in a practical article about librarians working in technical positions entitled, "How to Hack it as a Working Parent" by Bedoya, Heller, Salazar, and Yan (2015). Connell's addition to the field provides a survey of parental leave policies available to academic librarians (2013). 
The small handful of studies discussing librarianship and parenthood over the last 30 years includes three notable studies. Irvine's seminal 1985 study of "the malady known as 'intraoccupational sex segregation"” within academic libraries focused on the differences between male and female library administrators (p. 235). Using a survey of ARL library administrators, she traced the demographic changes and the sex composition of the administrators through the 1970s. Noting the marital and family tradeoffs female administrators seemed to make in efforts to reach the top, she stated, "For women making career decisions regarding executive positions, the prognosis is rather discouraging for combining family and career lives" (p. 253). While Irvine's study is not centered on motherhood, it illuminates the now decades-old position of female academic librarians and potentially a key distinction between men and women advancing in the profession.

Twenty years later, Zemon and Bahr (2005) usher Irvine's work into the twenty-first century and narrow the focus to measure the extent to which female library directors have been able to advance their career and also raise children. Using a survey to collect information, they found that the majority of directors who were also mothers reported that motherhood did not influence their advancement; additionally, female directors without children and female directors with at least one child reported similarly high levels of satisfaction with their career goal attainment, at $74.2 \%$ and $74.9 \%$ respectively. Female directors with children stated that the most significant factor in managing both a career and motherhood was a supportive spouse (p. 400).

Graves et al. (2008) build on Irvine and Zemon and Bahr by examining the relationship between librarians' tenure achievement and parenthood. Graves et al. used a combination of closed questions, Likert-like scales, and open comments in their anonymous surveys of male and female tenure-track and tenured librarians at ARL libraries. While very few of the librarians they 
surveyed reported postponing having children because of the promotion and tenure process, the authors noted that, "Female faculty still have more fear than their male colleagues that their personal family choices will negatively impact their career path" (p. 209). This distinction is curious because of the oft-cited feminized nature of the library profession. Graves et al. urged library leaders and administrators to make it clear to tenure-track librarians that they need not choose between tenure and becoming a parent. Their study concluded with a call to action to support and reassure early-career faculty.

All three of the aforementioned studies bolster the present study on academic librarianship and motherhood, but they do not provide ample opportunity to hear the voices and lived experiences of the librarians themselves. What do librarians who are mothers actually experience? Some of their challenges are apparent in the previous studies, but, with the work of Ward and Wolf-Wendel in mind, what are the benefits and rewards of combining librarianship and motherhood? In order to more deeply understand the experiences of librarians who are mothers and fill in the gaps in the literature with the voices of the women for whom this is a reality, it is necessary to use an open, qualitative approach. The present study attempts to add to this small body of relevant library literature by using a broader, more-inclusive sample, expanding the exploration to include non-ARL librarians and non-faculty librarians, and by using in-depth qualitative interviews instead of surveys.

\section{METHODOLOGY}

\section{Research Design.}

The relatively small body of research in the area of librarianship and parenthood (e.g., Zemon \& Bahr, 2005; Graves, et al., 2008; Connell, 2012) relies almost exclusively on survey 
methods and quantitative methods; the lived experiences of librarians who are mothers (or father) of young children is curiously absent from the literature, except in autobiographical essays or personal narratives. This study takes a constructivist, phenomenological approach to the examination of librarianship and motherhood, similar to the methods used in Trepal and Stinchfield (2012). Phenomenology allows the focus of the study to rest on the lived experiences of a group of individuals who have been through a common situation (i.e., living the dual roles of librarian and mother), and then develop a "composite description of the essence of the experience" (Creswell, 2012, p. 76). This is not to imply that all librarian-moms are the same; yet the similarities between them is substantial and those similarities can help express the larger phenomenon. The study seeks to examine participants' recollections, thoughts, expression of their emotions, and stories in order to shed light on what librarians who are mothers are experiencing, and, in this part of the larger study, what joys and benefits are they experiencing because they have combined librarianship and motherhood.

In-depth interviews comprising open-ended questions were used to capture participants' lived experiences. For example, the first interview question was "What has your experience been of being a mother and a full-time librarian?" This question was intentionally vague so that the participant could interpret her experience however she wanted. Participants were encouraged to take the questions at face value and answer them to the extent they felt comfortable; the openness of the questions often led to seemingly unrelated details and richer data. This holistic approach was necessary in order to describe participants' experiences instead of imposing a structure based on the literature or on others' experiences. Throughout the interviews, the author prompted participants to elaborate on their responses by asking, "Can you tell me more about that?" or "What does that mean to you?" (See Appendix A.) 


\section{Study Sample.}

In March 2014, a call for participants and an initial questionnaire were sent out to eight listservs. ${ }^{2}$ Recipients were asked to forward the call to other interested librarian-moms. The call for participation questionnaire asked respondents for their contact information, and included questions to determine if they qualified for the study (e.g., was the respondent a full-time librarian working in an academic library and the mother of a child/children age 4 or younger) and a request for suggestions for areas of inquiry.

The focus of the present study is exclusively on mothers rather than parents. While fathers clearly face challenges in combining work and family life, similar challenges faced by women in academic positions are exacerbated by the physical demands of pregnancy, childbirth, and breastfeeding (for biological mothers); the simultaneous ticking of the biological and tenure/promotion clocks; and, significantly, the socio-cultural assumptions and expectations of what ideal mothering looks like (Armenti, 2004; Raddon, 2005; Ward and Wolf-Wendel, 2005).

Of the 276 completed survey responses, 238 qualified for the research study. Public librarians, librarians outside the United States, fathers, and mothers of older children were excluded, as were respondents whom the author knew personally or professionally. Using a random-number generator, the author selected 25 respondents to contact via email to request an interview. Ultimately, 21 semistructured interviews were conducted in July 2014 using Skype or Google Hangouts. The shortest interview was 37 minutes and the longest was 97 minutes, with the average interview length at about one hour. All but two interviews were video interviews;

\footnotetext{
${ }^{2}$ Listservs used for call for participation, March 2014: Oberlin Group Reference Services List (Consortium of Liberal Arts College Libraries); ILI-L: ACRL Instruction Section; NMRT-L: ALA New Members Round Table Discussion; GLBTRT-L: ALA Gay Lesbian Bisexual and Transgender Round Table; Scholars: ALA Spectrum Scholar List; Rare Books and Manuscripts; ARLIS-L: Art Libraries Society of North America; CORAL-L: Council of Research and Academic Libraries Discussion List.
} 
two were voice-only (non-video), one at the request of the subject and one because of technical issues. All 21 interviews were saved via Camtasia Relay to a private, secure, password-protected YouTube channel so that the author could view/listen and transcribe them. The author also took extensive handwritten notes during the interviews and used transcriptions of the notes as an aid to the videos. Interview subjects were all given pseudonyms to protect their anonymity and privacy, and all children's names were removed. To ensure deeper anonymity within the close community of librarianship, no institutional names or identifying information about institutions are used throughout the study.

Only full-time employed librarians who are mothers of children age four and younger participated in the study. Participants could have children older than age four as well, as long as at least one of their children was younger than five. While participants' demographic data was not used to draw conclusions in this study, it is appropriate to acknowledge the study sample here. Of the 21 participants, 11 had one child (two were pregnant with a second child); eight participants had two children (one was pregnant with her third child); and two participants had three children. Nineteen of the participants were married; 17 were married to men and two were married to women. Two participants were single mothers. Sixteen self-identified as "white" or "Caucasian"; two as "white and Jewish"; two as "Asian"; and one as "Middle-Eastern." The ages of the 21 participants ranged from 29 to 46 years, with 36 as the median age and 39 as the mode. The academic librarians interviewed represented a variety of four-year institutions. Ten were employed at research universities, seven public institutions and three private. Four worked at undergraduate-focused universities, two public and two private. Seven participants worked at small, private colleges. Many of the institutions represented are widely considered prestigious colleges and universities. 
The Joy of Combining Librarianship and Motherhood 12

Participants' institutions varied on whether librarians were considered non-tenure-eligible faculty, eligible for tenure, or administrative staff. One third of participants were in supervisory or leadership positions (e.g., head of a department or an associate university librarian).

\section{Analysis Procedures.}

Transcriptions of the interviews and accompanying handwritten notes were coded and analyzed by the author using Dedoose, a web-based, qualitative data analysis software product. Because it was the author's first time using Dedoose, and she wanted an additional check, she also did a significant amount of manual coding to compare categories. Initially the plan was to explore the entire phenomenon of dual roles of librarianship and motherhood, and the author started to analyze all aspects of the data to build categories and themes. Subsequently the author decided to split the large project into smaller parts; this part of the larger study concentrates exclusively on the joys experienced by the participants and so analysis was focused on participants' positive experiences and perceived benefits and rewards.

Transcriptions and notes were interpreted using an inductive approach. This inductive, qualitative analysis method was appropriate because although there is a body of research on motherhood and academia broadly, there is little descriptive research on motherhood and academic librarianship in particular. This study began with detailed observations (i.e., the interviews) and moved from specifics to more abstract generalizations/ideas. Qualitative techniques are appropriate here because the topic is grounded in the women's life experiences and their own articulation of those experiences.

The author used a "bracketing" procedure to separate her own experiences from those of the participants, following the example from previous phenomenological literature on academia and motherhood (Trepal \& Stinchfield, 2012, p. 117; Creswell, 2012, p. 80). Before conducting 
The Joy of Combining Librarianship and Motherhood 13

any of the interviews, she wrote out her own responses to the interview questions and checked it to be sure that her interpretations of the participants' experiences were not biased by her own experiences as a librarian-mom. The intention here was to ensure that the participants' experiences were the sole focus of the study. The author maintained a thorough audit trail throughout the research and analysis process.

Because the purpose of this article is to understand the lived experiences of the women interviewed, it seemed important to use the participants' words themselves. For this reason, many longer, richer quotations are included in the Discussion section.

\section{FINDINGS}

As the purpose of this paper is to highlight the joys and rewards of combining academic librarianship with motherhood, these findings will not belabor the challenges and sacrifices of the dual roles, although, to be sure, all the participants mentioned their conflicted feelings and ambivalent experiences. The researcher was immediately struck by how often participants spoke positively and even exuberantly about loving both their roles as librarian and as mother. It should be noted that it was clear from each participant's interview that she loved her children and found great joy in being a mother; this joy was sometimes in conflict with and sometimes amplified by her feelings about her work as a librarian. The heart of the findings is drawn from a quote from one of the women interviewed: "Being a librarian has made me a better mother, and being a mom has actually made me a better librarian" (Nicole, a research and instruction librarian and mother of identical twins). This bi-directional work-family enrichment sentiment was echoed to an extent in most of the participants' interviews, although rarely so succinctly (see Greenhaus \& Powell, 2006, for review of "work-family enrichment" concept). With this guiding concept in 
The Joy of Combining Librarianship and Motherhood 14

mind, multiple themes emerged. Examples of participants expressing that they were better mothers because of their librarian role as well as better librarians because of their mother role are evident throughout the 21 interviews. Six key themes focused on the rewards of combining these two roles emerged from the data: (1) pride in professional identity, (2) time away from children, (3) being a role model, (4) sharing the values of librarianship, (5) increased sensitivity to students, and (6) avoidance of professional burnout. The following section will elaborate on each of these six themes.

Additionally, most of the participants noted the benefits of having a dual-income family as an obvious reward for working as a librarian with young children at home. Four participants explicitly stated that their decision to work outside the home while raising young children was not a choice at all; financial constraints (notably student loan debt) mandated that these librarians continue to work full-time. While the theme of family economics was evident in most of the interviews, this theme does not seem to be unique to librarianship but rather is a recurring theme for full-time employed mothers in the United States. So while it is a significant benefit, it is not included in this discussion of the rewards of combining librarianship and motherhood.

\section{DISCUSSION}

\section{Pride in Professional Identity.}

The author did not anticipate how often and how fervently the participants would express their passion for their work and identity as librarians. In fact, it was their joy based in professional identity that led the author to concentrate this study on the multiple joys of combining librarianship and motherhood and to seek literature relevant to this topic. In their paper entitled "Academic Motherhood: Managing Complex Roles in Research Universities," 
Ward and Wolf-Wendel introduce the joy of professional and personal roles as a theme in their interviews with 29 faculty who were professors and mothers (2004). They note that the joy they heard from their subjects was largely absent from the scholarly literature. The joy they highlight is echoed and amplified in the interviews with the participants of this study. Many participants mentioned feeling "lucky" that they have a job they "love" and get to do work they "can feel proud of.” Maggie, a liaison librarian and mother of one, remarked that, "I am very much attached to 'I am a librarian' and I love that. That feels like who I am, even when I say that right now." Participants gushed about the satisfaction they get from their work as librarians, for example:

"I do work that I can feel proud of. Like, I feel like I'm doing something good in the world, making the world a little better by teaching students how to do research. Making, you know, an impact. My favorite part of my job is the research consultations. [...] I end up doing about 100 a year and I pretty much always come away from them feeling like that was a lot of fun, that was so exciting, like I genuinely helped [students] with their projects, like they are grateful for the work that I do. It's just fulfilling to be able to work with these really bright students on their exciting projects. That's where I get a lot of my satisfaction from. And it's important to me that I have all that. And to have an identity as a librarian, to have that be, like, part of who I am" (Laura, reference and instruction librarian and mother of two).

Many participants explained that they had been a librarian before becoming a mother, and that their identity as a librarian was important to hold on to while going through motherhood: "It wasn't something that I wanted to give up."

Similar to the results presented in Ward and Wolf-Wendel (2004), part of the joy of being a librarian while being a mother comes from modeling a pleasurable career for one's children. The author will elaborate upon this later in this section ("Being a Role Model”).

\section{Time Away from Children.}

The second most prevalent theme that emerged from the interviews was the joy participants felt about being able to both love their children and also spend time apart from them. 
More than half of the 21 participants $(62 \%)$ mentioned that having time away from their children — whether their children are in daycare, in-home care, with a nanny, or with a spouseas a key benefit of working outside the home as a librarian, and that this time away made them better mothers. Significantly, this is not a benefit or reward from combining work and motherhood that appears explicitly in the sociological, psychological, library science, or management literature. This "break" from children was exemplified by this quotation:

"On a good day, I think working and being a librarian and doing what I like to do makes me a better mom. I think being able to get out of the house and to have -- it sounds awful to say it out loud -- but to have a break from my children and to have time to myself is really valuable. It allows me to go home and have missed them during the day and give them undivided attention when I'm home because I've had that time away. I think it makes me nicer sometimes. It makes me feel more fulfilled because I get to get out and do something I care about beyond caring for my children" (Katherine, access services librarian and mother of two).

Another participant's comments echoed this, as she explained that for her, being a "good mom" is about "being present": "I feel like if I was home all the time, I wouldn't be present. I wouldn't be able to be present with them and happy and really bring my whole self to them. Whereas now I feel like I can. I can, even though I'm tired, I can bring my whole mom self when I'm with them. Because now I have this part of my life that is mine, all mine, at work" (Angela, head of access services and mother of two).

Other participants mentioned feeling "isolated", "lonely", or "unfulfilled" at home during their maternity leave and being eager to get back to work, despite feeling sad about leaving their children. Three participants explained that they felt that daycare itself was a tremendous benefit to their children because the kids were getting something that the participant herself could not provide. For example, Amanda, an outreach librarian and mother of two children, explained that "as hard as it was to leave my babies in childcare when they were babies, I really see how it was a benefit to them. Because now they are fearless girls, and I'm so proud of that. 
They really walk into situations ready to talk to people and be friendly and participate and join in. [...] [Daycare] was really beneficial and gave them something I couldn't have given them on my own, made them the people that they are."

Another participant said that her son's daycare teaches him Spanish and "gives him opportunities I definitely would not be giving him if I was a stay-at-home mom" (Stephanie, discovery services librarian and mother of 1).

Laura values the break from her children and sees it as a benefit to her whole family. She put it this way:

"I think my kids get a better version of me. I think if I were with them all the time I would go crazy. My husband works every other weekend too, and those weekends when I'm alone with them for two whole days [...] by Sunday night I'm, like, so ready to get back to work. It's intense being with them, and not having a little release valve if they are being crazy. You know how kids can get crazy sometimes and can get on your nerves and you just need a moment to step away and have a moment with your own thoughts for a minute. On those weekends alone with them, I just don't have that. I just don't think I'd be very suited for full-time parenting or stay-at-home parenting. They get this better version of me because I get to go to work and I'm thankful that I can do that."

Perhaps this phenomenon of feeling relieved to be away from one's children is ignored in the current literature because it is contrary to the concept of the good mother (one exception being Raddon, 2002). According to the traditional and still-pervasive myth, the "good mother" is the intensive, selfless mother, who is entirely absorbed and engaged with her sacred child or children, and where the needs of the child always take precedence over the needs of the mother (Thurer, 1995; Johnston \& Swanson, 2006). Traditionally, it is assumed that the "good mother" is set in conflict with the "successful academic" or "ideal worker" (Raddon, 2002; Williams, 2005). It would make sense that mothers would not want to portray themselves as antithetical to the "good mother." The fact that so many study participants cited having time away from their 
children as a joy and a benefit pushes firmly against the good mother myth, and, in shattering it, gives voice to the realities of combining librarianship and motherhood.

\section{Being a Role Model.}

Throughout their interviews, several participants talked about wanting to be a positive role model for their children; it was a comment that came up again and again especially when participants were asked about the benefits of combining motherhood with librarianship. This is one quotation that is representative of a typical comment:

"I feel very strongly about modeling a career for my kids. That I want them to understand that basically girls can do everything. Especially now that [my daughter] is getting to that age where she has this really hard-line attitude about gender roles, that boys do this and girls do that. [...] I want to be sure that she has models of women doing things in her life that she can look up to. And, like, all my friends work, so I can talk to my girls about how women are strong and women do all different types of jobs and that sort of thing." (Amanda)

Ward and Wolf-Wendel (2004) describe how female faculty enjoy showing their children examples of adults enjoying the work that they do. Jessie, a reference and instruction librarian and mother of three, explains how modeling the complexity of adulthood is important to her:

"The benefits are that my kids get to see me as a professional as well, they get to see me in a different dimension than just being their mom. And I think that is important. I think there are a lot of images that come across in children's lives that are can lay a foundation for making assumptions about women and what women are in this country, and I think it's good for them, for my daughters and for my son as well, in terms of them seeing their mom in a situation where I'm interacting with the public, and I'm interacting in a professional way with the parents of their friends but then they also see me having those people over for play dates. I think it's good for them, for them to see that there are all these different dimensions to people's lives."

Enjoying modeling professionalism and working outside the home is a benefit cited by women outside of librarianship as well; it is not unique to this profession. It was still noticeable that over 
The Joy of Combining Librarianship and Motherhood 19

half the participants interviewed mentioned this as a joy they received from combining

librarianship and motherhood.

\section{Sharing the Values of Librarianship.}

While some of the joys of combining work with parenthood mentioned by participants could be more broadly applicable to any profession, there were a few particular to librarianship, specifically, the joy participants found in sharing the values and lessons of librarianship with their children. Most often, this joy was evident in response to the prompt, "What sort of goals and expectations do you have for yourself as a librarian and as a mother?" All the participants spoke lovingly of their children, and mentioned wanting to raise children who are "happy," “confident," "open-minded," "aware," and "open to experiences." Six participants mentioned that they also wanted to raise their children to be "critical of the world" and three mentioned wanting their children to "be aware of [their] privilege in the world." Jessie explained,

"I feel like my kids are going to be way more fluent about research and information and scrutinizing information. You know, thinking about information literacy, even with little kids. Not just research, but having my kids be critical consumers of information. I think it is just an important thing for them to be able to read between the lines of the messages they are receiving, whether that's from the kids on the playground at daycare or when they are flipping through magazines or seeing a commercial on TV and thinking to themselves, 'OK, what are they trying to sell me? What is really going on here?'”

Participants seemed to want to share the values of librarianship — awareness, critical evaluation, and recognition of privilege — with their children, and saw this sharing of their professional selves as something that made them better mothers.

\section{Increased Sensitivity to Students.}

Several participants explicitly underscored how being a mother has made them feel like better librarians because of their newfound sensitivity toward students. Three participants relayed lengthy stories about a distracted or sick student in a library session, and how the participant 
handled situation differently because of her dual role as a librarian and as a mother. Lisa, an

information literacy librarian and single mother of one, poignantly described her feelings toward

her students since becoming a mother:

"Something that happens now is that I notice students. I look at students and think, 'they are so beautiful.' I always cared, but since my daughter, I look at students, really look at them, and I think 'that is a human life.' I feel like not until you've added a human life to the world can you totally appreciate it in that way. So I'm glad I'm a working mom in that way."

Nicole, a research and instruction librarian and mother of twins, echoed these sentiments, stating that,

"Again, I think being a mother makes me a better librarian. I think I have a new perspective on dealing with students and working with students than I did before children. I think I am more sensitive to them as people, as someone's daughter or son. So yeah, I think I'm a richer person and a better librarian and better educator but I'm definitely a more tired person."

Academic librarians often find themselves playing multiple roles for their students (e.g., research help, instructor, advisor), so it was interesting to hear how the additional role of mother changed that dynamic. As a distance-education librarian who primarily works with nontraditional students, Nikta, a mother of a infant, found that her role as a new mother improved her interactions with her students:

"I have to be kind of like a crisis counselor and a librarian. I have to be someone who bends over backwards to help my students. And a lot of time it's not about helping them use databases or resources. It's interesting because a lot of them are, you know, middleaged women who are single mothers and are going back to school, and it's more about sitting there and talking to them about how hard it is to be a mother and be going back to school when you have kids. So it's more like counseling sessions. And now I can talk to them more than before [my daughter arrived] because now I get it, I get how hard it is. My position feels more like librarian-slash-counselor. I feel like I understand them as a librarian and as a mom who is trying."

The librarian-moms' newfound sensitivity toward and changed perspective about their students was an unexpected theme that emerged from the interviews. It might be interesting to 
The Joy of Combining Librarianship and Motherhood 21

specifically investigate how the librarian's personal status (from non-mother to mother) has changed her student interactions to explore whether these interactions have actually changed or just the librarian's feelings about the interactions have changed. Regardless, the librarians who mentioned this sensitivity felt a definite change in their understanding of their students.

\section{Avoidance of Professional Burnout.}

While all participants mentioned the challenges of schedules, routines, sleeplessness, and coordinating dueling responsibilities, a few highlighted how being a mother had actually helped them maintain professional energy. Some of the literature on academic faculty and parenthood points to higher productivity and increased efficiency of faculty who are parents (e.g., Kyvik, 1990; Toren, 1991; Sax, Hagedorn, Arredondo, \& Dicrisi, 2002). Only two of the participants interviewed for this study, Miriam and Jessie, alluded to that literature. Miriam, a digital services librarian with a 6-month old, stated that she had expected to be more efficient upon returning to work because she had read such literature before giving birth, but found that she was significantly less-efficient since becoming a mother. Another participant, Jessie, described how before becoming a mother and even after each of her first two children, she was "terrible with [her] time" but now, after her arrival of her third child, she

“just want[s] to be a mom when I'm at home, and I have to work really hard on motivation and time management so that I can do that. I try to manage my time way better than I ever did. I don't want to have work in the back of my head, I just want to be mom.[...] Before I had kids, I was way more amenable to coming in on the weekends or staying late, and now I don't do that or at least I really try not to. I think it actually makes me a better librarian when I'm at work, because I can be all business, and then I can turn off work at the end of the day. If I didn't have this attitude, I think I would, like, burn out at work, because I'd just be trying to do [work] all the time instead of setting aside time and then turning it off."

Two participants discussed how maintaining a "firm" boundary between their work lives and home lives was an important part of their strategy for maintaining balance and avoiding burnout 
at work. Maggie explained that she had more energy when she was at work because she does not take work home with her:

"I am pretty adamant about not doing work outside of work. [...] And since becoming a librarian, even before becoming a mother, I am just very firm about that boundary between work and life. Because this isn't that kind of job and I don't want it to be that. Not a lot of my colleagues think that way. You know, they always expect you to be available. [...] Becoming a mother only heightened that feeling for me, that wanting a firm boundary between work and non-work time. As I said, a big part of my true identity is being a librarian, but so is my outside life and my outside interests. And I feel very strongly about doing those things when I'm gone from work. Being a mom has only made that more so and I think I'm a better at my work because of those limits that I set between work and non-work. I am stubborn about this."

Having at least one young child made these librarian-moms draw a harder line between their work lives and their family lives, and they viewed this division as the key to their professional energy and potential longevity in the profession. Instead of trying to find a way to seamlessly combine home and work life, they have chosen to set these limits in the hope that they will have more motivation and energy for each sphere of their lives, motherhood and librarianship.

\section{LIMITATIONS AND FURTHER RESEARCH}

The findings of this study represent the first part of a larger study of the lived experiences of librarians who are also mothers of young children. Because it is only part of a larger study, it necessarily comprises only a segment of the librarian-moms' experiences; this report does not dwell on the myriad challenges, conflicts, and ambivalences these participants experience. The intent here is not to gild the reality but rather to highlight one aspect: the joys and benefits of combining these two roles.

There are additional limitations to be considered. The sample of academic librarians used for this study was intentionally broad. Although participant demographic information was 
collected and could be used in the future, this analysis did not draw distinctions based on institutional type (e.g., research university, liberal arts college, community college), on librarian status (e.g., tenure-track, tenure, faculty, staff), on position or level (e.g., reference librarian, head of digital services librarian, associate university librarian), or on career stage (e.g., earlycareer vs. mid-career).

Additionally, the homogeneity of the sample may be considered a limitation. The findings say little about librarian-moms who are women of color, who have adopted their children, who are single mothers, who are in same-sex partnerships, who are sole breadwinners, or who have children with disabilities. While the sample does include some of these populations, these were not the focus nor can any meaningful conclusions be drawn. It would be interesting to see a study based on one or more of these populations.

When the author sent out a call for participation, she received over a dozen emails inquiring about her focus exclusively on mothers (and not on fathers, or on both). Some of the emails seemed merely curious, and others suggested sexism as the reason for the choice. While this study centers on the experiences of mothers, a different phenomenological study examining the experiences of librarian-dads - or one comparing the experiences of women and men with children — would certainly be useful to the profession.

Notably, this study focuses exclusively on women who are mothers of young children: only mothers with children age four and younger were interviewed. While this is a reasonable and strategic choice for a study exploring what early motherhood looks like for librarians, especially in the years preceding formal schooling, it is significant that this study in no way attempts to capture librarians' varying experiences over their lifetime role as mothers. A librarian might have a drastically different perspective at different stages of her child's life and her life as 
The Joy of Combining Librarianship and Motherhood 24

a mother. This study glimpses at a fraction of a librarian-mom's experiences. It would be interesting to see a longitudinal study of librarians who are combining work and motherhood.

Planned future research based on the data collected will include an examination of participants' professional and personal identity as a librarian-mom, participants' educational and career goals for themselves, and participants' experiences that could lead to institutional policy change within universities and libraries (e.g., parental leave, ability to breastfeed/pump at work, access to affordable childcare, flexible work schedules, managing tenure or promotion).

\section{CONCLUSION}

As revealed in Raddon (2005) and Ward and Wolf-Wendel (2004; 2012), there is room in the scholarly literature for a positive perspective on the obvious challenges of working in academia and being a mother; this study highlights some of the joys that women have experienced when combining academic librarianship and motherhood. Although the participants in this study know just how hard managing their dual roles can be - they have all felt the dueling expectations of and the tension between the two roles - they nonetheless still see benefits in their choice to be both a librarian and a mom. The positive effects noted by librarians who are also mothers included: experiencing pride in their professional identity, having time away from their children, contributing to the family economy, being a role model to their children, sharing the values of librarianship, having an increased sensitivity toward their students, and avoiding professional burnout. Why does our profession not openly discuss the issue of motherhood in our scholarly journals? Why should a librarian who looks to the literature for guidance find nothing that reflects her professional experience? Graves et al. (2008) called upon librarians to break the silence and begin a dialogue, but years have passed and little has changed. Librarians have 
remained mostly silent for too long, and we would better serve our institutions, each other, and ourselves if we were to speak up, share our stories, and take a leadership role in this conversation. 


\section{APPENDIX A. INTERVIEW PROTOCOL}

--Introductions

--Explain that participants can stop at any time, participation is voluntary and anonymous

--Explain that I will be asking two sets of questions: demographic and experiential

--Ask permission to take notes and to record the interview

Demographic Questions

Confirm name and institution

What is your position title?

How long have you been at this job?

What status do librarians have at your institution: staff, faculty, tenure-track, other?

(If relevant) What are you in that process?

How many children do you have?

(Ask their names to create more comfort.)

How old are your kids?

Are you raising them with a partner or a co-parent?

Does the co-parent live with you?

How would you describe your race or ethnicity?

How old are you?

\section{Experiential Questions}

Explain that some questions might seem broad or vague; answer them however you think makes the most sense for you and your experiences.

1. What has your experiences been of being a mother and a full-time librarian?

2. How would you describe your identity as a librarian and as a mom?

3. How would you describe balance and what does balance look like to you?

4. What kind of support do you feel you have or do not have as a librarian-mom? Support could be from your partner, family, friends, local groups, supervisor, colleagues, institutional policies, religious groups...

5. Can you describe any experience you've had with breastfeeding?

6. What does your childcare situation look like?

7. What do you see as the benefits and sacrifices of being a full-time librarian and a mom?

8. What sorts of goals and expectations do you have for yourself as a librarian and as a mother?

9. What strategies or tips would you have wanted another mom to have shared with you?

10. Do you have anything else you'd like to add or to ask me? 
The Joy of Combining Librarianship and Motherhood 27

\section{REFERENCES}

Acker, S., \& Armenti, C. (2004). Sleepless in academia. Gender and Education, 16(1), 3-24. doi: $10.1080 / 0954025032000170309$

Armenti, C. (2004). Women faculty seeking tenure and parenthood: Lessons from previous generations. Cambridge Journal of Education, 34(1), 65-83. doi:

$10.1080 / 0305764042000183133$

Bedoya, J., Heller, M., Salazar, C., \& Yan, M. (2015). How to Hack it as a Working Parent. The Code4Lib Journal, 28(April 15, 2015). http://journal.code4lib.org/articles/10409

Bird, S. R. (2011). Unsettling universities' incongruous, gendered bureaucratic structures: A case- study approach. Gender, Work \& Organization, 18(2), 202-230. doi: 10.1111/j.1468-0432.2009.00510.x

Connell, R. S. (2012). Maternity and paternity policies available to academic librarians. College \& Research Libraries, crl-339.

Creswell, John W. (2012). Qualitative inquiry and research design: Choosing among five approaches. Thousand Oaks, CA: Sage.

Graves, S. J., Xiong, J. A., \& Park, J. H. (2008). Parenthood, professorship, and librarianship: Are they mutually exclusive? The Journal of Academic Librarianship, 34(3), 202-210. doi: 10.1016/j.acalib.2008.03.003

Greenhaus, J. H., \& Powell, G. N. (2006). When work and family are allies: A theory of workfamily enrichment. Academy of Management Review, 31(1), 72-92. doi:

10.5465/AMR.2006.19379625 
Hollenshead, C. S., Sullivan, B., Smith, G. C., August, L., \& Hamilton, S. (2005). Work/family policies in higher education: Survey data and case studies of policy implementation. New Directions for Higher Education, 2005(130), 41-65. doi: 10.1002/he.178

Irvine, B. J. (1985). Differences by sex: Academic library administrators. Library trends, 34(2), 235-257. http://citeseerx.ist.psu.edu/viewdoc/download?doi=10.1.1.172.9543\&rep=rep1\&type=pdf \#page $=80$

Johnston, D. D., \& Swanson, D. H. (2006). Constructing the "good mother": The experience of mothering ideologies by work status. Sex Roles, 54(7-8), 509-519. doi: 10.1007/s11199006-9021-3

Kyvik, S. (1990). Motherhood and scientific productivity. Social Studies of Science, 20(1), 149160. doi: $10.1177 / 030631290020001005$

Mason, M. A., Wolfinger, N. H., \& Goulden, M. (2013). Do babies matter?: Gender and family in the ivory tower. Piscataway: Rutgers University Press.

Munn-Giddings, C. (1998). Mixing motherhood and academia-A lethal cocktail. In D. Malina and S. Maslin-Prothero (Eds.), Surviving the academy: Feminist perspectives (pp. 56-68). London: Falmer Press.

O’Laughlin, E. M., \& Bischoff, L. G. (2005). Balancing parenthood and academia work/family stress as influenced by gender and tenure status. Journal of Family Issues, 26(1), 79-106. doi: $10.1177 / 0192513 X 04265942$

O'Meara, K., Terosky, A. L., \& Neumann, A. (2008). Faculty Careers and Work Lives: A Professional Growth Perspective. ASHE Higher Education Report, 34(3), 1-221. ERIC Number: EJ822663 
Raddon, A. (2002). Mothers in the Academy: positioned and positioning within discourses of the' successful academic' and the 'good mother'. Studies in Higher Education, 27(4), 387403. doi: 10.1080/0307507022000011516

Sax, L. J., Hagedorn, L. S., Arredondo, M., \& Dicrisi III, F. A. (2002). Faculty research productivity: Exploring the role of gender and family-related factors. Research in higher education, 43(4), 423-446.

Toren, N. (1991). The nexus between family and work roles of academic women in Israel: Reality and representation. Sex Roles, 24(11-12), 651-667. doi:10.1007/BF00288204

Thurer, S. (1995). The myths of motherhood: How culture reinvents the good mother. New York: Penguin.

Trepal, H. C., \& Stinchfield, T. A. (2012). Experiences of motherhood in counselor education. Counselor Education and Supervision, 51(2), 112-126. doi:10.1002/j.15566978.2012.00008.x

U.S. Department of Education, National Center for Education Statistics, 2008-2009 Integrated Postsecondary Education Data System, Table 300, Fall 2009. http://nces.ed.gov/pubs2011/2011015_3b.pdf

Van Anders, S. M. (2004). Why the academic pipeline leaks: Fewer men than women perceive barriers to becoming professors. Sex roles, 51(9-10), 511-521. doi: 10.1007/s11199-004$5461-9$

Ward, K. \& Wolf-Wendel, L. (2004). Academic motherhood: Managing complex roles in research universities. The Review of Higher Education, 27(2), 233-257.

Ward, K. \& Wolf- Wendel, L. (2005). Work and family perspectives from research university faculty. New Directions for Higher Education, 2005(130), 67-80. 
Ward, K. \& Wolf-Wendel, L. (2012). Academic motherhood: How faculty manage work and family. New Brunswick, NJ: Rutgers University Press.

Williams, J. C. (2005). The glass ceiling and the maternal wall in academia. New Directions for Higher Education, 2005(130), 91-105.

Zemon, M., \& Bahr, A. H. (2005). Career and/or children: Do female academic librarians pay a price for motherhood? College \& Research Libraries, 66(5), 394- 406.

http://doi.org/10.5860/crl.66.5.394 